\title{
SYNTHESIS AND SOME REACTIONS OF 11-AZACYCLOHEPT[a]AZULEN-3(3H)-ONES AND EVALUATION OF THEIR CYTOTOXIC ACTIVITY AGAINST HELA S3 CELLS
}

\author{
Tomoyuki Ariyoshi, ${ }^{1}$ Kengo Yoshinaga, ${ }^{2}$ Kazuya Koizumi, ${ }^{1}$ Hiroyuki Fujii, ${ }^{3}$ \\ Reiko Ikeda, ${ }^{4}$ Takeo Konakahara, ${ }^{4}$ and Noritaka Abe ${ }^{1 *}$
}
${ }^{1}$ Applied Molecular Bioscience, Graduate School of Medicine, and Department of Biology and Chemistry, Faculty of Science, Yamaguchi University, Yoshida, Yamaguchi 753-8512, Japan
${ }^{2}$ Department of Biology and Chemistry, Faculty of Science, Yamaguchi University, Yamaguchi 753-8512, Japan
${ }^{3}$ Science Research Center, Yamaguchi University, Yamaguchi 753-8512, Japan
${ }^{4}$ Department of Pure and Applied Chemistry, Faculty of Science and
Technology,Tokyo University of Science, Noda, Chiba 278-8510, Japan

\begin{abstract}
Aldol condensation of 2,3-diformyl-1-azaazulene with acetone, methoxyacetone, and benzylacetone in aq. $\mathrm{NaOH}$ solution gave corresponding 11-azacyclohept[a]azulen-3(3H)-one (2a), 2-methoxy-derivative (2b) and 2-benzyl-derivative (2d) in good yields. Hydrolysis of $\mathbf{2 b}$ using hot $\mathrm{HBr}$ gave 2-hydroxy-11-azacyclohept[a]azulen-3(3H)-one (2f). Acetylation of $2 \mathbf{f}$ gave 2-acetoxy-11-azacyclohept[a]azulen-3(3H)-one (2g). Reaction of the compounds (2a, 2b, 2f) with diethyl malonate in $\mathrm{Ac}_{2} \mathrm{O}$ under heating gave 1,9(11bH)-11b-azaazuleno[1,2,3-cd] azulenedione derivatives (4a, $\mathbf{4 b}, \mathbf{4 f})$. Compounds (2b, 2f) showed weak cytotoxic activity against HeLa S3 cells.
\end{abstract}

\section{INTRODUCTION}

Tricyclic and tetracyclic systems of containing azulene nucleus such as azulenotropylium ions, azulenotropones and azulenoazulenes are attracted attentions form the view of aromaticity and bioactivity. $^{1-3}$ Several azulenotropones and azulenoazulenes have been synthesized notably by $\mathrm{K}$. Takase, ${ }^{4-6}$ C. Jutz, ${ }^{7}$ T. Toda, ${ }^{8}$ Z. Yoshida, ${ }^{9}$ and S. Kuroda, ${ }^{10}$ and M. Nitta. ${ }^{11}$ Although many researches 
of fused azaazulene chemistry were proceeding, ${ }^{12}$ researches about aza-analogs of azulenotropylium ions, azulenotropones, and azulenoazulenes were few, ${ }^{13-16}$ and the report was not observed about the reaction of azaazulenotropones except the $N$-protonation ${ }^{13,14}$ and the $N$-methylation ${ }^{14}$. Recently, we reported the synthesis of 2,3-diformyl-1-azaazulene, ${ }^{17}$ which would be a key product for construction of fused 1-azaazulene systems. We now report the facile synthesis 11-azacyclohept[a]azulen-3(3H)-ones (11-azaazuleno[1,2-d]tropones) (2) and the addition-cyclization reaction of $\mathbf{2}$ with diethyl malonate.

\section{RESULTS AND DISCUSSION}

Treatment of 2,3-diformyl-1-azaazulene (1) with acetone in aq. $\mathrm{NaOH}$ solution for $10 \mathrm{~min}$ at rt gave 11-azacyclohept[a]azulen-3(3H)-one (2a) in 48\% yield. It is reported that 2a was prepared by the oxidation of dicyclohepta[b,d]pyrrole with $\mathrm{MnO}_{2}$ by Nitta, but the yield low (9\%) and the reaction of $2 \mathrm{a}$ was scarcely investigated. ${ }^{14)}$ In the ${ }^{1} \mathrm{H}$ NMR spectrum of $\mathbf{2 a}$, seven-membered ring protons in the azaazulene moiety were seen at $\delta 7.96$ (ddd, $J$ 9.8, 9.6, and 0.4, H-7), 8.03 (dd, $J 10.0$ and 9.8, H-9), 8.15 (t, $J$ 9.8, H-8), 8.88 (dd, $J 10.0$ and 0.4, H-10), and 8.93 (d, $J$ 9.6, H-6), where bond-alternation was not observed. On the other hand, seven-membered ring protons of tropone moiety were seen at $\delta 6.95$ (dd, $J$ 12.1 and 2.4, H-4), 7.25 (d, $J 12.4$ and 2.4, H-2), 8.07 (d, $J$ 12.1, H-5), and 8.08 (d, $J$ 12.4, H-1). The results suggest that $\mathbf{2 a}$ would have a 1,4-pentadien-3-one fused with 1-azaazulene structure. Unfortunately, we could not obtain a favorable crystal of $\mathbf{2 a}$ for the X-ray analysis. Therefore, to clarify the consideration, we performed the molecular orbital calculation by Gaussian '03 using RHF/6-31G*18. The calculated bond lengths for 2a, shown in Fig. 1, supported our consideration.

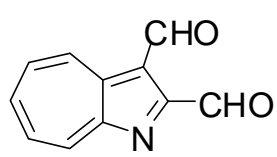

1

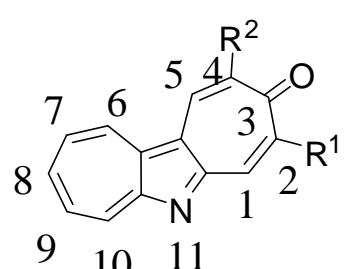

$9 \quad 10 \quad 11$

2a $: \mathrm{R}^{1}=\mathrm{R}^{2}=\mathrm{H}$

2b : $\mathrm{R}^{1}=$ OMe, $\mathrm{R}^{2}=\mathrm{H}$

2c $: \mathrm{R}^{1}=\mathrm{H}, \mathrm{R}^{2}=\mathrm{OMe}$

2d : $\mathrm{R}^{1}=\mathrm{CH}_{2} \mathrm{Ph}, \mathrm{R}^{2}=\mathrm{H}$

2e : $\mathrm{R}^{1}=\mathrm{R}^{2}=\mathrm{CO}_{2} \mathrm{Et}$

2f : $\mathrm{R}^{1}=\mathrm{OH}, \mathrm{R}^{2}=\mathrm{H}$

2g: $\mathrm{R}^{1}=\mathrm{OAC}, \mathrm{R}^{2}=\mathrm{H}$

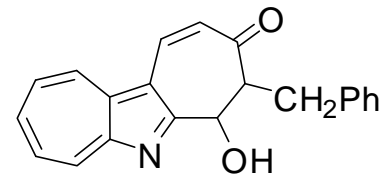

3

The condensation of $\mathbf{1}$ with acetone underwent in good yield. Therefore, our method is superior to Nitta's method. The method could be extended to the reaction with other acetone derivatives. Thus 1 was treated with methoxyacetone in aq. $\mathrm{NaOH}$ solution for $10 \mathrm{~min}$ at $\mathrm{rt}$ to give only 
2-methoxy-11-azacyclohept[a]azulen-3(3H)-one

(2b)

in

$63 \%$

yield,

and

4-methoxy-11-azacyclohept $[a]$ azulen-3(3H)-one ${ }^{13}$ (2c) was not obtained. Melting point of obtained compound (mp 214-215 ${ }^{\circ} \mathrm{C}$ ) differed from that of the reported 2c (mp 209.5-211.5 $\left.{ }^{\circ} \mathrm{C}\right)^{13}$. The electronic spectra of $\mathbf{2} \mathbf{b}$ and $\mathbf{2} \mathbf{c}^{13}$ were distinctly different as shown in Fig. 2 . In the ${ }^{1} \mathrm{H}$ NMR spectrum of $\mathbf{2 b}$, methoxy proton was seen at $\delta 4.11$, and a singlet signal assigned to $\mathrm{H}-1$ proton was seen at $\delta 7.68$ and AB-doublet protons were seen at $\delta 7.13(1 \mathrm{H}, \mathrm{d}, J 12.2, \mathrm{H}-4) 8.17(1 \mathrm{H}, \mathrm{d}, J 12.2, \mathrm{H}-5)$, except for the seven-membered ring protons of the azaazulene moiety. From the results, we assigned the structure.

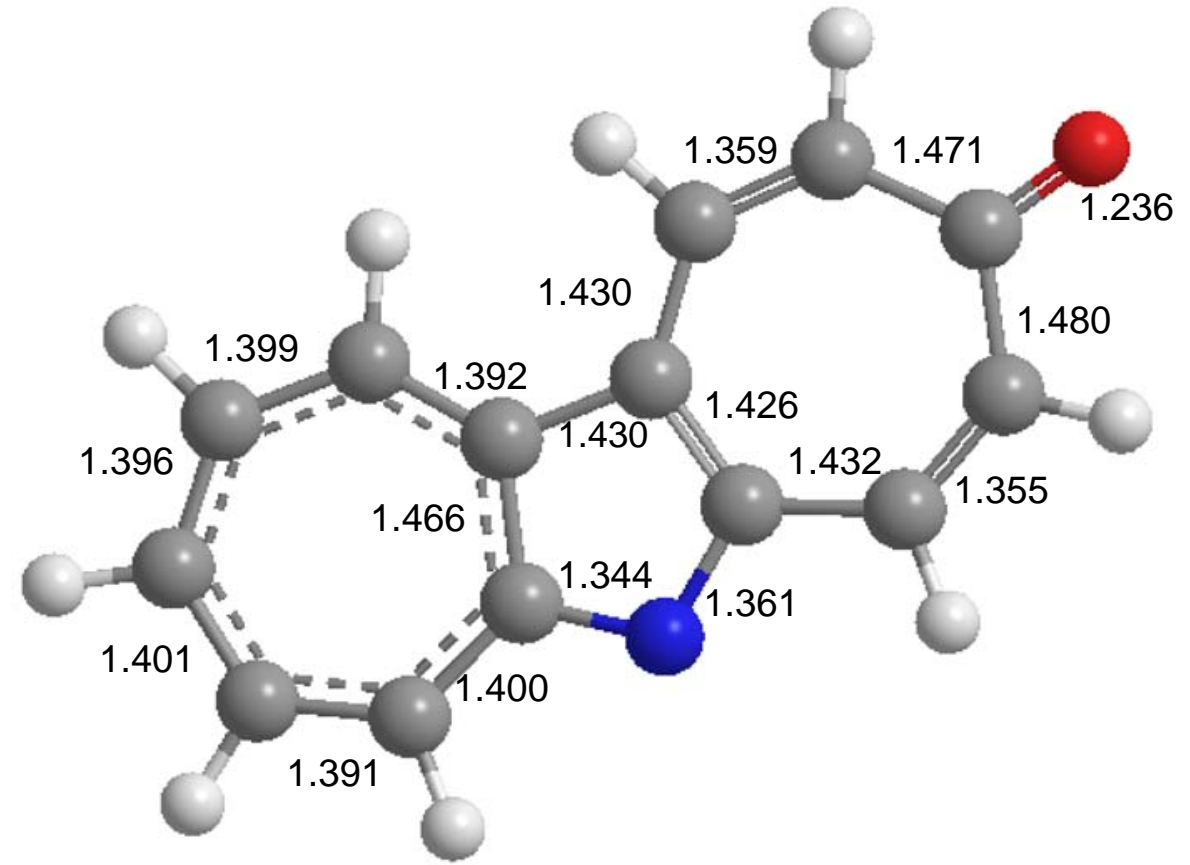

Figure 1. Calculated bond lengths and the optimized structure of $\mathbf{2 a}$.

When 1 was treated with benzylacetone for $10 \mathrm{~min}$ at rt, 2d (34\%) and 3 (22\%) were obtained. In the ${ }^{1} \mathrm{H}$ NMR spectrum of 3 , two methine protons were observed at $\delta 3.56(1 \mathrm{H}$, dddd, $J$ 8.1, 7.7, 6.0, and 1.2, $\mathrm{H}-2), 5.21(1 \mathrm{H}, \mathrm{d}, J 6.0, \mathrm{H}-1)$ and benzyl protons were seen at $\delta 2.60(1 \mathrm{H}, \mathrm{dd}, J 13.8$ and 7.7$)$ and 2.77 $(1 \mathrm{H}, \mathrm{dd}, J 13.8$ and 8.1), except for the seven-membered ring protons of the azaazulene moiety. In the ${ }^{13} \mathrm{C}$ NMR spectrum of 3, two methine carbons were observed at $\delta 59.1$ and 68.8 together with benzyl carbon at $\delta$ 34.3. In the IR spectrum of 3, characteristic peaks were observed at $3444(\mathrm{OH}), 1623(\mathrm{C}=\mathrm{O})$, and $1603 \mathrm{~cm}^{-1}(\mathrm{C}=\mathrm{C})$. From the results, we assigned the structure. Prolonged treatment of 1 with benzylacetone (for $2 \mathrm{~h}$ at $\mathrm{rt}$ ) gave $\mathbf{2 d}$ in $74 \%$ yield and none of $\mathbf{3}$. It is considered that intermediate (3) was obtained at first, then successive dehydration afforded $\mathbf{2 d}$.

Similar treatment of $\mathbf{1}$ with diethyl 1,3-acetonedicarboxylate gave $\mathbf{2 e}$ in $13 \%$ yield. For improvement of the yield, $\mathbf{1}$ was treated under azeotropic conditions in the presence of $\mathrm{NHEt}_{2}$ in benzene under reflux for $4 \mathrm{~h}$, but $2 \mathrm{e}$ was obtained only in $5 \%$ yield. 
Hydrolysis of $\mathbf{2 b}$ was achieved by treatment with $48 \% \mathrm{HBr}$ under reflux for $3 \mathrm{~h}$ and 2-hydroxy-11-azacyclohept[a]azulen-3(3H)-one (2f) was obtained in $88 \%$ yield. Compound $2 \mathbf{f}$ was acetylated with $\mathrm{Ac}_{2} \mathrm{O}$ in the presence of pyridine for $1 \mathrm{~h}$ at rt, and 2-acetoxy-11-azacyclohept[a]azulen-3(3H)-one (2g) was obtained in 61\% yield, where the isomeric acetate could not be isolated.

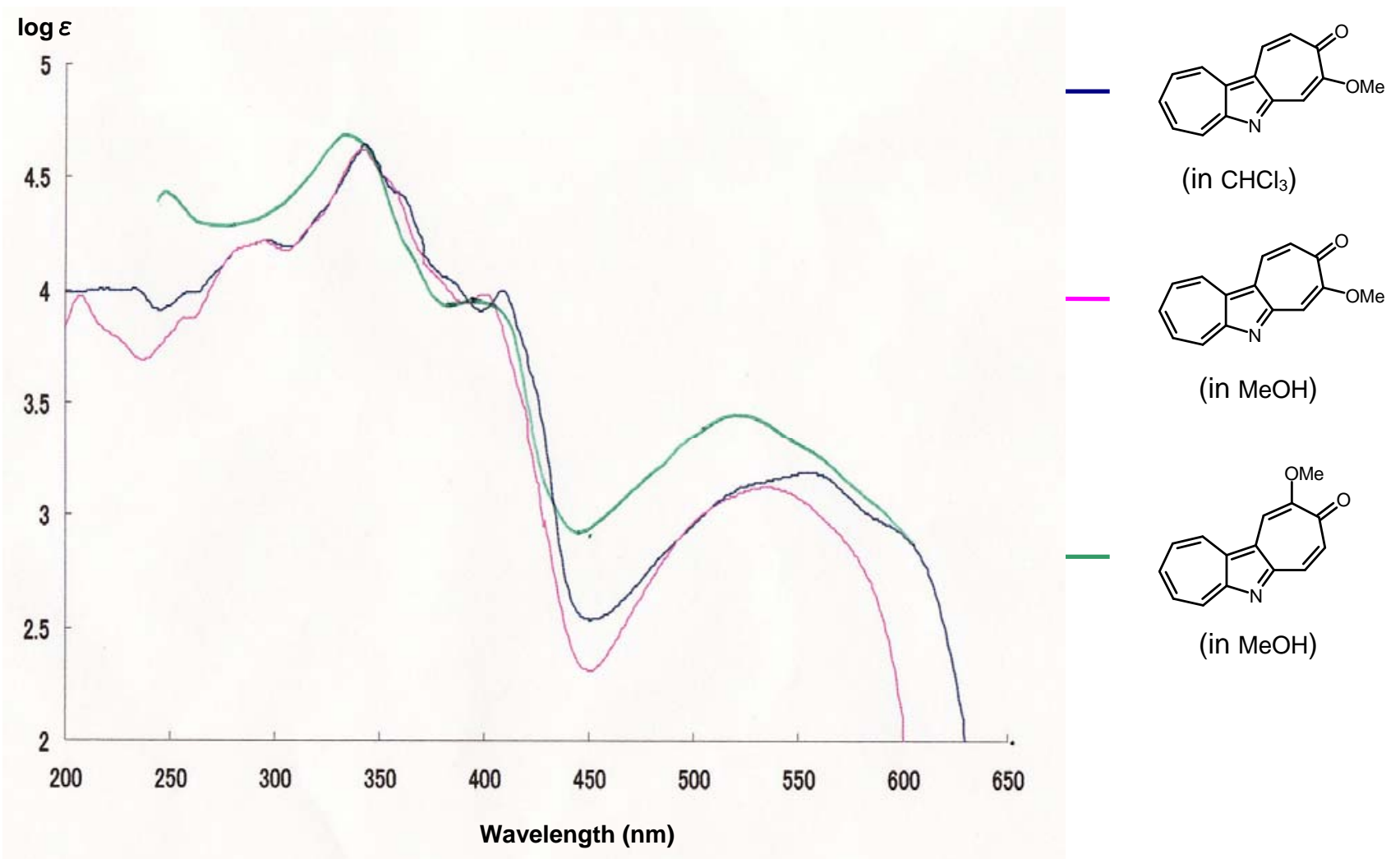

Figure 2. Electronic spectra of $\mathbf{2} \mathbf{b}$ and $\mathbf{2 c}$.

It is well known that 8,8-dicyanoheptafulvene was obtained by the condensation of tropone with malononitrile in refluxing $\mathrm{Ac}_{2} \mathrm{O} .{ }^{19}$ Therefore we examined the reaction of 2a with malononitrile, but distinct product was not isolated. When 2a was treated with diethyl malonate in refluxing $\mathrm{Ac}_{2} \mathrm{O}$ for 1.5 h gave 11b-azaazuleno[1,2,3-cd]azulene-1,9(11bH)-dione derivative (4a) in $24 \%$ yield. In the ${ }^{1} \mathrm{H}$ NMR spectrum of $\mathbf{4 a}$, one ethyl ester signals were observed at $\delta 1.45(J 7.1, \mathrm{Me})$ and $4.43\left(\mathrm{~J} 7.1, \mathrm{OCH}_{2}\right)$ and four proton signals owing to seven-membered ring of azaazulene moiety were seen at $\delta 7.51$ (dd, $J$ 10.4 and 10.3, H-5), 7.81 (dd, $J 11.0$ and 10.3, H-4), 8.04 (d, $J$ 10.4, H-6), and 8.71 (d, $J$ 11.0, H-3), and tropone moiety at $\delta 7.07$ (dd, $J 12.2$ and 2.5, H-8), 7.22 (dd, $J 12.4$ and 2.5, H-10), 7.73 (dd, $J 12.2, \mathrm{H}-7$ ), and 8.48 (d, $J$ 12.4, H-11). In the IR spectrum of $\mathbf{4 a}$, three carbonyl signals were seen at 1738,1674 , and $1619 \mathrm{~cm}^{-1}$, owing to ester, $\gamma$-lactim, and tropone carbonyls, respectively. From the results, we 
assigned the structure. Michael addition of the enol form of diethyl malonate to the C-10 of 2a would generate intermediate $\mathbf{A}$, and successive cyclization and dehydrogenation furnished to $\mathbf{4 a}$.

Similar treatment of $\mathbf{2 b}$ and $\mathbf{2 d}$ with diethyl malonate in refluxing $\mathrm{Ac}_{2} \mathrm{O}$ gave $\mathbf{4 b}(39 \%)$ and $\mathbf{4 f}$ (25\%), respectively.

As 2a was not reacted at the carbonyl of tropone moiety as above, we examined the reaction of $\mathbf{2 a}$ with 2,4-dinitrophenyl hydrazine to substantiate the reactivity. But we could not obtain distinct products, and failed to elicit the reactivity of the carbonyl group.

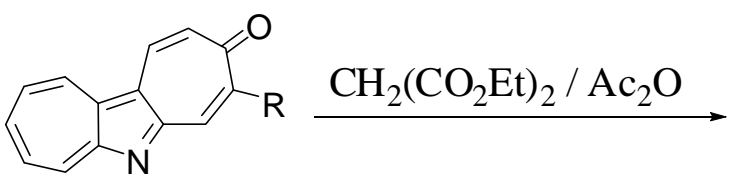

2a : $\mathrm{R}=\mathrm{H}$

2b : $\mathrm{R}=\mathrm{OMe}$

2f : $\mathrm{R}=\mathrm{OH}$

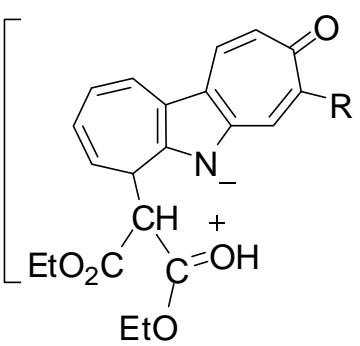

A

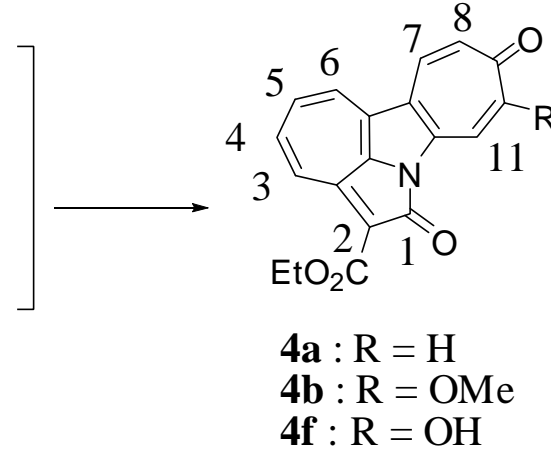

\section{Evaluation of cytotoxic activity}

Compounds (2b and $\mathbf{2 f}$ ) were evaluated for their cytotoxic activity against HeLa S3 cells. The IC 50 values $[\mu \mathrm{M}]$ were 41 and 19 for $\mathbf{2 b}$ and $\mathbf{2 f}$, respectively. The results revealed that the compounds (2b and 2f) showed weak activity against HeLa S3 cells.

\section{EXPERIMENTAL}

Mps are measured using a Yanagimoto micro-melting apparatus and uncorrected. ${ }^{1} \mathrm{H}$ NMR spectra (including HH-COSY and CH-COSY NMR) were recorded on a Bruker AVANCE 400S (400 MHz) and ${ }^{13} \mathrm{C}$ NMR spectra were recorded on a Bruker AVANCE $400 \mathrm{~S}(100.6 \mathrm{MHz})$ using $\mathrm{CDCl}_{3}$ as a solvent with tetramethylsilane as an internal standard unless otherwise stated; $J$ values are recorded in $\mathrm{Hz}$. IR spectra were recorded for $\mathrm{KBr}$ pellets on a Nicolet FT-IR AVTAR 370DTGS unless otherwise stated. Electronic spectra were recorded with JASCO V-570 spectrophotometer. Elemental analyses were taken with a Perkin Elmer 2400II. Kieselgel 60 and activated alumina C300 were used for column chromatography and Kieselgel 60G was used for thin-layer chromatography.

\section{Synthesis of 11-azacyclohept $[a]$ azulen-3(3H)-one (2a)}

A solution of 2,3-diformyl-1-azaazulene (1) (0.0988 g, $0.534 \mathrm{mmol})$ and $\mathrm{Me}_{2} \mathrm{CO}$ (0.06 mL, $0.82 \mathrm{mmol}$ ) in $0.11 \mathrm{M} \mathrm{NaOH}$ solution $(100 \mathrm{~mL}, 1.1 \mathrm{mmol})$ was stirred for $10 \mathrm{~min}$ at room temperature. The mixture was extracted with $\mathrm{CH}_{2} \mathrm{Cl}_{2}$. The extract was dried over $\mathrm{Na}_{2} \mathrm{SO}_{4}$, and evaporated. The residue was 
chromatographed with EtOAc to give 2a (0.0531 g, 48\%) as purple powders.

2a: Purple micro needles (from EtOH), mp $195{ }^{\circ} \mathrm{C}$ (decomp.); $\delta_{\mathrm{H}} 6.95$ (1H, dd, $J 12.1$ and 2.4, H-4), 7.25 (1H, d, $J 12.4$ and 2.4, H-2), 7.96 (1H, ddd, $J$ 9.8, 9.6, and 0.4, H-7), 8.03 (1H, dd, $J 10.0$ and 9.8, H-9), 8.07 (1H, d, $J$ 12.1, H-5), 8.08 (1H, d, $J$ 12.4, H-1), 8.15 (1H, t, $J$ 9.8, H-8), 8.88 (1H, dd, $J 10.0$ and 0.4, H-10), and 8.93 (1H, d, $J$ 9.6, H-6); $\delta_{\mathrm{H}}(\mathrm{TFA}-d) 7.71$ (1H, dd, $J 12.0$ and 2.0, H-4), $7.92(1 \mathrm{H}, \mathrm{d}, J$ 12.1 and 2.0, H-2), 8.47 (1H, d, 12.1, H-1), 8.83 (1H, dd, $J 10.0$ and 9.9, H-7), 8.86 (1H, dd, $J 10.1$ and 9.8, H-9), 8.88 (1H, d, J 12.0, H-5), 8.98 (1H, dd, $J 10.0$ and 9.8, H-8), 9.39 (1H, d, $J$ 10.1, H-10), and 9.87 (1H, d, J 9.9, H-6); $\delta_{\mathrm{C}} 107.5,120.0,130.4,131.9,132.5,135.8,138.7,139.9,134.0,141.0,141.4$, 143.6, 149.7, and 184.9; $v_{\max } / \mathrm{cm}^{-1} 1592(\mathrm{C}=\mathrm{O}) ; \lambda_{\max }\left(\mathrm{CHCl}_{3}\right) \mathrm{nm}(\log \varepsilon) 286$ (4.11), 328 (4.52), 342 (4.66), 360 (3.97, sh), 385 (3.86), 406 (3.42), 500 (2.82, sh), 541 (3.03, sh), 568 (3.07), and 616 (2.84, sh); $\lambda_{\max }(\mathrm{MeOH}) \mathrm{nm}(\log \varepsilon) 286$ (4.16), 328 (4.60), 342 (4.72), 358 (4.06, sh), 384 (3.93), 406 (3.49), 541 (3.15, sh), 566 (3.17), and 607 (2.97, sh). Anal. Calcd for $\mathrm{C}_{14} \mathrm{H}_{9} \mathrm{NO} \cdot \mathrm{H}_{2} \mathrm{O}$ : C, 74.65; H, 4.92; N, 6.22. Found: C, 74.44; H, 4.98; N, 6.19.

\section{Synthesis of 2-methoxy-11-azacyclohept[a]azulen-3(3H)-one (2b)}

A solution of $1(0.0981 \mathrm{~g}, 0.530 \mathrm{mmol})$ and methoxyacetone $(0.07 \mathrm{~mL}, 0.76 \mathrm{mmol})$ in $0.055 \mathrm{M} \mathrm{NaOH}$ solution (200 mL, $1.1 \mathrm{mmol}$ ) was stirred for $10 \mathrm{~min}$ at rt. The mixture was extracted with $\mathrm{CH}_{2} \mathrm{Cl}_{2}$. The extract was dried over $\mathrm{Na}_{2} \mathrm{SO}_{4}$, and evaporated. The residue was chromatographed with EtOAc to give $\mathbf{2 b}(0.0795 \mathrm{~g}, 63 \%)$ as reddish purple leaflets.

2b: Reddish purple leaflets (from hexane- $\mathrm{CH}_{2} \mathrm{Cl}_{2}$ ), mp 214-215 ${ }^{\circ} \mathrm{C}$; $\delta_{\mathrm{H}} 4.11$ (3H, s, OMe), $7.13(1 \mathrm{H}, \mathrm{d}, J$ 12.2, H-4), 7.68 (1H, s, H-1), 7.95 (1H, td, J 9.4 and 1.2, H-7), 7.99 (1H, ddd, J 9.6, 9.4, and 1.2, H-9), 8.10 (1H, ddd, $J$ 9.6, 9.4, and 1.4, H-8), 8.17 (1H, d, $J$ 12.2, H-5), 8.77 (1H, dd, $J 9.6$ and 1.4, H-10), and 8.86 (1H, d, J 9.4, H-6); $\delta_{\mathrm{H}}(\mathrm{TFA}-d) 4.35$ (3H, s, OMe), 7.92 (1H, d, J 11.9, H-4), 8.13 (1H, s, H-1), 8.81-8.96 (3H, m, H-7, 8, and 9), 9.06 (1H, d, $J$ 11.9, H-5), 9.36 (1H, d, $J$ 9.9, H-10), and 9.82 (1H, d, $J$ 9.8, H-6); $\delta_{\mathrm{C}} 56.7,110.1,121.9,128.2,129.4,130.9,132.9,133.1,137.1,139.0,144.9,160.0,161.3$, 162.4, and 181.7; $v_{\max } / \mathrm{cm}^{-1} 1614(\mathrm{C}=\mathrm{O}) ; \lambda_{\max }\left(\mathrm{CHCl}_{3}\right) \mathrm{nm}(\log \varepsilon) 259$ (3.99), 284 (4.19, sh), 296 (4.22), 322 (4.34, sh), 343 (4.64), 358 (4.43, sh), 382 (4.05, sh), 409 (4.00), 528 (3.14, sh), 555 (3.19), and 592 (2.96, sh); $\lambda_{\max }(\mathrm{MeOH}) \mathrm{nm}$ (log $\left.\varepsilon\right) 258$ (3.88), 285 (4.19, sh), 294 (4.22), 318 (4.29, sh), 341 (4.63), 376 (4.07, sh), 400 (3.98), and 535 (3.12). Anal. Calcd for $\mathrm{C}_{15} \mathrm{H}_{11} \mathrm{NO}_{2} \cdot 2 \mathrm{H}_{2} \mathrm{O}: \mathrm{C}, 70.02 ; \mathrm{H}, 5.88 ;$ N, 5.44. Found: C, 70.12; H, 5.88; N, 5.34.

\section{Reaction of 1 with benzylacetone}

a) A solution of 1 (0.093 g, $0.502 \mathrm{mmol})$ and benzylacetone $(0.113 \mathrm{~g}, 0.762 \mathrm{mmol})$ in $0.048 \mathrm{M} \mathrm{NaOH}$ solution (100 mL, $4.80 \mathrm{mmol}$ ) was stirred for $10 \mathrm{~min}$ at rt. The mixture was extracted with $\mathrm{CH}_{2} \mathrm{Cl}_{2}$. 
The extract was dried over $\mathrm{Na}_{2} \mathrm{SO}_{4}$, and evaporated. The residue was chromatographed with EtOAc to give $2 \mathbf{d}(0.0471 \mathrm{~g}, 34 \%)$ and 3 (0.0334 g, 22\%), successively.

b) A solution of $1(0.0370 \mathrm{~g}, 0.200 \mathrm{mmol})$ and benzylacetone $(0.113 \mathrm{~g}, 0.762 \mathrm{mmol})$ in $0.0445 \mathrm{M} \mathrm{NaOH}$ solution (100 mL, $4.45 \mathrm{mmol}$ ) was stirred for $2 \mathrm{~h}$ at rt. The mixture was extracted with $\mathrm{CH}_{2} \mathrm{Cl}_{2}$. The extract was dried over $\mathrm{Na}_{2} \mathrm{SO}_{4}$, and evaporated. The residue was chromatographed with EtOAc to give 2d (0.0442 g, 74\%).

2d: violet powders (from hexane- $\left.\mathrm{CH}_{2} \mathrm{Cl}_{2}\right), \mathrm{mp} 208-210{ }^{\circ} \mathrm{C} ; \delta_{\mathrm{H}} 4.14\left(2 \mathrm{H}, \mathrm{s}, \mathrm{CH}_{2}\right), 7.01(1 \mathrm{H}, \mathrm{d}, J 12.2$, H-4), 7.23 (1H, tt, $J 7.2$ and 2.2, H-p-Ph), 7.31 (2H, dd, $J 7.7$ and 7.2, H-m-Ph), 7.37 (2H, dd, $J 7.7$ and 2.2), H-o-Ph), 7.91 (1H, dd, $J 9.8$ and 9.5, H-7), 7.97 (1H, dd, $J 9.9$ and 9.6, H-9), 8.01 (1H, d, $J$ 12.2, H-5), 8.08 (1H, dd, $J 9.9$ and 9.8, H-8), 8.12 (1H, s, H-1), 8.79 (1H, d, J 9.6, H-10), and 8.86 (1H, d, $J$ 9.5, H-6); $\delta_{\mathrm{C}} 40.9,124.0,126.5,128.3,128.6,129.6,130.5,131.1,132.3,124.5,134.6,138.6,139.2,140.1$, 144.5, 152.1, 159.1, 161.8, and 187.3; $v_{\max } / \mathrm{cm}^{-1} 1597(\mathrm{C}=\mathrm{O})$. Anal. Calcd for $\mathrm{C}_{21} \mathrm{H}_{15} \mathrm{NO} \mathrm{H}_{2} \mathrm{O}$ : C, 79.98; H, 5.43; N, 4.44. Found: C, 79.66; H, 5.32; N, 4.64.

3: Red powders (from hexane- $\mathrm{CH}_{2} \mathrm{Cl}_{2}$ ), mp $202{ }^{\circ} \mathrm{C}$ (decomp.); $\delta_{\mathrm{H}} 2.60$ (1H, dd, $J 13.8$ and 7.7, $\mathrm{C}_{2}$ ), 2.77 (1H, dd, $J 13.8$ and 8.1, $\left.\underline{\mathrm{H}}_{2}\right)$, 3.56 (1H, dddd, $J$ 8.1, 7.7, 6.0, and 1.2, H-2), 5.21 (1H, d, $J$ 6.0, H-1), 6.24 (1H, d, $J 12.3$ and 1.2, H-4), 6.94 (2H, dt, $J 7.5$ and 1.5, H-o-Ph), 7.11 (1H, tt, $J 7.0$ and 1.5, H-p-Ph), 7.16 (2H, dd, $J 7.5$ and 7.0, H-m-Ph), 7.56 (1H, d, $J$ 12.3, H-5), 7.76 (1H, dd, $J 10.0$ and 9.7, H-7), 7.80 (1H, dd, $J 9.8$ and 9.7, H-9), 7.97 (1H, ddd, $J$ 9.8, 9.7, and 0.8, H-8), 8.57 (1H, d, $J$ 10.0, H-6), and 8.63 (1H, dd, $J 9.5$ and 0.8, H-10), (OH was not observed); $\delta_{\mathrm{C}} 34.3,59.1,68.8,119.5,125.9,126.3,128.3$, 128.9, 130.5, 131.6, 133.8, 137.6, 138.3, 139.7, 144.5, 157.0, 169.9, and 196.9; $v_{\max } / \mathrm{cm}^{-1} 3444(\mathrm{OH})$, $1623(\mathrm{C}=\mathrm{O})$, and $1603(\mathrm{C}=\mathrm{C})$. Anal. Calcd for $\mathrm{C}_{21} \mathrm{H}_{17} \mathrm{NO}_{2}: \mathrm{C}, 79.98 ; \mathrm{H}, 5.43 ; \mathrm{N}, 4.44$. Found: $\mathrm{C}$, 80.06; H, 5.52; N, 4.28.

\section{Reaction of 1 with diethyl acetone-1,3-dicarboxylate}

a) A solution of 1 (0.0951 g, $0.514 \mathrm{mmol})$ and diethyl acetone-1,3-dicarboxylate $(0.20 \mathrm{~mL}, 1.20 \mathrm{mmol})$ in $0.25 \mathrm{M} \mathrm{NaOH}$ solution (50 mL, $1.25 \mathrm{mmol}$ ) was stirred for $10 \mathrm{~min}$ at rt. The mixture was extracted with $\mathrm{CH}_{2} \mathrm{Cl}_{2}$. The extract was dried over $\mathrm{Na}_{2} \mathrm{SO}_{4}$, and evaporated. The residue was chromatographed with EtOAc to give $2 \mathbf{e}(0.0215$ g, 13\%) as violet powders.

b) To the solution of diethyl acetone-1,3-dicarboxylate $(0.20 \mathrm{~mL}, 1.20 \mathrm{mmol})$ and $\mathrm{NHEt}_{2}(0.15 \mathrm{~mL})$ in dry benzene ( $50 \mathrm{~mL}$ ) was added benzene solution (20 mL) of 1 (0.1149 g, $0.625 \mathrm{mmol})$, and the mixture was refluxed for $4 \mathrm{~h}$ using Dean-Stark trap. The mixture was evaporated and the residue was chromatographed with EtOAc to give $2 \mathbf{e}(0.0015$ g, 5\%)

2e: Violet powders (from AcOEt), mp 148-149 ${ }^{\circ} \mathrm{C}$; $\delta_{\mathrm{H}} 1.41$ (3H, t, $J$ 7.0, Me), 1.42 (3H, t, $J$ 7, Me), 4.43 (4H, q, $J$ 7.0, $\mathrm{CH}_{2}$ ), 8.05 (1H, dd, $J 10.1$ and 9.9, H-9), 8.10 (1H, dd, $J 9.8$ and 9.5, H-7), 8.23 (1H, dd, $J$ 
9.9 and 9.5, H-8), 8.55 (1H, s, H-1), 8.77 (1H, s, H-5), 8.93 (1H, d, J 10.1, H-10), and 9.05 (1H, d, J 9.5, H-6); $\delta_{\mathrm{C}} 14.1,14.2,61.9,62.1,122.9,130.9,131.5,131.6,133.3,134.2,136.3,140.3,141.1,141.8,145.9$, 159.8, 160.8, 166.2, 167.1, and 184.2; $v_{\max } / \mathrm{cm}^{-1} 1736,1695$, and $1626(\mathrm{C}=\mathrm{O}) ; \lambda_{\max }\left(\mathrm{CHCl}_{3}\right) \mathrm{nm}(\log \varepsilon)$ 296 (4.32, sh), 334 (4.59), 341 (4.58), 376 (4.12, sh), 523 (3.00, sh), 553 (3.04), and 592 (2.84, sh). Anal. Calcd for $\mathrm{C}_{20} \mathrm{H}_{17} \mathrm{NO}_{5}$ : C, 68.37; H, 4.88; N, 3.99. Found: C, 68.57; H, 4.93; N, 3.75.

\section{Synthesis of 2-hydroxy-11-azacyclohept[a]azulen-3(3H)-one (2f)}

A mixture of $\mathbf{2 b}(0.0317 \mathrm{~g}, 0.134 \mathrm{mmol})$ and $48 \% \mathrm{HBr}(10 \mathrm{~mL})$ was stirred for $3 \mathrm{~h}$ under heating at $160{ }^{\circ} \mathrm{C}$. The mixture was neutralized with $\mathrm{Na}_{2} \mathrm{CO}_{3}$ and extracted with $\mathrm{CHCl}_{3}$. The extract was dried over $\mathrm{Na}_{2} \mathrm{SO}_{4}$, and evaporated. The compound $2 \mathbf{f}(0.0263 \mathrm{~g}, 88 \%)$ was obtained as purple powders.

2f: Purple scales (from EtOH-EtOAc), mp 178-180 ${ }^{\circ} \mathrm{C}$; $\delta_{\mathrm{H}} 5.11(1 \mathrm{H}, \mathrm{br}, \mathrm{OH}), 7.31(1 \mathrm{H}, \mathrm{d}, J 12.0, \mathrm{H}-4)$, 7.97 (1H, ddd, $J$ 9.6, 9.5 and 1.4, H-7), 8.04 (1H, ddd, $J$ 9.6, 9.3, and 1.4, H-9), 8.07 (1H, s, H-1), 8.08 (1H, dd, $J 9.6$ and 9.5, H-8), 8.43 (1H, d, $J$ 12.0, H-5), 8.82 (1H, dd, $J 9.3$ and 1.8, H-10), and 8.88 (1H, d, $J$ 9.5, H-6); $\delta_{\mathrm{C}} 11.9,122.8,123.8,125.0,131.9,132.7,133.4,135.2,137.4,139.0,145.5,160.4,161.0$, 162.6, and 180.3; $v_{\max } / \mathrm{cm}^{-1} 3249(\mathrm{OH})$ and $1625(\mathrm{C}=\mathrm{O}) ; \lambda_{\max }\left(\mathrm{CHCl}_{3}\right) \mathrm{nm}(\log \varepsilon) 276$ (4.04), 292 (4.06), 300 (4.09), 321 (4.16), 339 (4.32, sh), 350 (4.38), 391 (3.80, sh), 396 (3.78, sh), 410 (3.68, sh), 428 (3.44, sh), 510 (3.20), 533 (3.18), and 581 (2.91, sh); $\lambda_{\max }(\mathrm{MeOH}) \mathrm{nm}(\log \varepsilon) 259$ (3.77), 265 (3.82), 285 (3.95, sh), 297 (4.05, sh), 320 (4.23), 360 (4.29), 409 (3.65), 506 (3.79), and 531 (3.78); $\lambda_{\max }(\mathrm{MeOH}+1$ drop of aq. $\mathrm{NaOH}) \mathrm{nm}(\log \varepsilon) 259$ (3.77), 265 (3.82), 285 (3.94, sh), 298 (4.05, sh), 321 (4.25), 359 (4.28), 424 (3.65), 508 (3.79), and 532 (3.78). Anal. Calcd for $\mathrm{C}_{14} \mathrm{H}_{9} \mathrm{NO}_{2} \cdot$ EtOAc: C, 69.44; H, 5.51; N, 4.50. Found: C, 69.41; H, 5.35; N, 4.24.

\section{Acetylation of $2 f$}

A mixture of $2 \mathbf{f}(0.0185 \mathrm{~g}, 0.083 \mathrm{mmol}), \mathrm{Ac}_{2} \mathrm{O}(1 \mathrm{~mL})$, and a drop of pyridine was stirred for $1 \mathrm{~h}$ at $\mathrm{rt}$. To the mixture water was added, and the mixture was extracted with $\mathrm{CHCl}_{3}$. The extract was dried over $\mathrm{Na}_{2} \mathrm{SO}_{4}$, and evaporated. The residue was chromatographed with EtOAc to give $\mathbf{2 g}(0.0134 \mathbf{g}, 61 \%)$ as violet powders.

2g: Violet needles (from MeOH-CH $\mathrm{Cl}_{2}$ ), mp $188{ }^{\circ} \mathrm{C}$; $\delta_{\mathrm{H}} 2.44(1 \mathrm{H}, \mathrm{s}, \mathrm{Me}), 7.10(1 \mathrm{H}, \mathrm{d}, J$ 12.2, H-4), 7.99 (1H, td, $J 10.0$ and 9.8, H-9), 8.05 (1H, dd, $J 9.8$ and 9.6, H-7), 8.10 (1H, s, H-1), 8.14 (1H, d, $J$ 12.2, H-5), 8.17 (1H, t, $J$ 9.8, H-8), 8.82 (1H, d, $J$ 10.0, H-10), and $8.88\left(1 \mathrm{H}, \mathrm{d}, J\right.$ 9.6, H-6); $\delta_{\mathrm{C}} 20.8,124.0$, 126.3, 129.4, 139.5, 131.0, 132.9, 135.0, 139.2, 140.8, 144.6, 155.6, 159.2, 159.5, 168.8, and 180.0; $v_{\max }$ $/ \mathrm{cm}^{-1} 1754$ and $1603(\mathrm{C}=\mathrm{O}) ; \lambda_{\max }\left(\mathrm{CHCl}_{3}\right) \mathrm{nm}(\log \varepsilon) 259$ (3.95), 288 (4.23, sh), 312 (4.36, sh), 327 (4.45), 340 (4.53), 360 (4.43), 384 (3.94, sh), 494 (3.82, sh), 503 (3.82), and 525 3.81, sh). Anal. 
Calcd for $\mathrm{C}_{16} \mathrm{H}_{11} \mathrm{NO}_{3}$ : C, 72.45; H, 4.18; N, 5.28. Found: C, 72.41; H, 4.33; N, 5.24.

\section{Reaction of 11-azacyclohept[a]azulen-3(3H)-ones (2a, 2b, 2f) with diethyl malonate}

A mixture of $2 \mathbf{a}(0.0872 \mathrm{~g}, 0.42 \mathrm{mmol})$ and diethyl malonate $(0.35 \mathrm{~mL}, 2.3 \mathrm{mmol})$ in $\mathrm{Ac}_{2} \mathrm{O}(10 \mathrm{~mL})$ was refluxed for $1.5 \mathrm{~h}$. To the mixture was added water, then the mixture was extracted with $\mathrm{CHCl}_{3}$. The extract was dried over $\mathrm{Na}_{2} \mathrm{SO}_{4}$, and evaporated. The residue was chromatographed with EtOAc to give 4a $(0.318 g, 24 \%)$ as red powders.

4a: Red powders (from $\mathrm{CH}_{2} \mathrm{Cl}_{2}$ ), mp 137-138 ${ }^{\circ} \mathrm{C} ; \delta_{\mathrm{H}} 1.45$ (3H, t, $J$ 7.1, Me), 4.43 (2H, q, $J$ 7.1, $\mathrm{OCH}_{2}$ ), 7.07 (1H, dd, $J 12.2$ and 2.5, H-8), 7.22 (1H, dd, $J 12.4$ and 2.5, H-10), 7.51 (1H, dd, $J 10.4$ and 10.3, H-5), 7.73 (1H, dd, $J$ 12.2, H-7), 7.81 (1H, dd, $J 11.0$ and 10.3, H-4), 8.04 (1H, d, $J$ 10.4, H-6), 8.48 (1H, d, $J$ 12.4, H-11), and 8.71 (1H, d, $J$ 11.0, H-3); $\delta_{\mathrm{C}} 14.5,60.4,125.0,126.5,128.6,129.4,130.3,130.9$, 131.4, 135.2, 136.7, 136.8, 139.0, 140.7, 141.8, 149.6, 162.3, 163.4 and 187.3; $v_{\max } / \mathrm{cm}^{-1} 1738,1674$, $1619(\mathrm{C}=\mathrm{O})$, and $1588(\mathrm{C}=\mathrm{C}) ; \lambda_{\max }\left(\mathrm{CHCl}_{3}\right) \mathrm{nm}(\log \varepsilon) 296$ (4.32, sh), 334 (4.59), 341 (4.58), 376 (4.12, sh), 418 (3.23, sh), 518 (2.99, sh), 553 (3.04), and 604 (2.77, sh). Anal. Calcd for $\mathrm{C}_{19} \mathrm{H}_{13} \mathrm{NO}_{4}$ : C, 71.47; H, 4.10; N, 4.39. Found: C, 71.53; H, 3.85; N, 4.21.

Similar treatment of $\mathbf{2 b}$ and $\mathbf{2 f}$ gave $\mathbf{4 b}$ (39\%) and $\mathbf{4 f}$ (21\%), respectively.

4b: Reddish brown powders (from cyclohexane), mp 223-224 ${ }^{\circ} \mathrm{C}$; $\delta_{\mathrm{H}} 1.46(3 \mathrm{H}, \mathrm{t}, J$ 7.1, Me), $4.12(3 \mathrm{H}, \mathrm{s}$, OMe), 4.45 (2H, q, J 7.1, $\mathrm{OCH}_{2}$ ), 7.24 (1H, d, $J$ 12.4, H-8), 7.58 (1H, dd, $J 10.3$ and 9.8, H-5), 7.83 (1H, d, $J$ 12.4, H-7), 7.85 (1H, dd, $J 11.0$ and 9.8, H-4), 8.11 (1H, d, $J$ 10.3, H-6), 8.27 (1H, s, H-11), and 8.79 $\left(1 \mathrm{H}, \mathrm{d}, J\right.$ 11.0, H-3); $v_{\max } / \mathrm{cm}^{-1} 1721,1690,1613(\mathrm{C}=\mathrm{O})$, and $1585(\mathrm{C}=\mathrm{C})$. Anal. Calcd for $\mathrm{C}_{20} \mathrm{H}_{15} \mathrm{NO}_{5}$ : C, 68.76; H, 4.33; N, 4.01. Found: C, 69.02; H, 4.55; N, 3.86.

4f: Red powders (from $\mathrm{CH}_{2} \mathrm{Cl}_{2}$ ), mp $132-133{ }^{\circ} \mathrm{C} ; \delta_{\mathrm{H}} 1.45\left(3 \mathrm{H}, \mathrm{t}, J\right.$ 7.1, Me), $4.43\left(2 \mathrm{H}, \mathrm{q}, J\right.$ 7.1, $\mathrm{OCH}_{2}$ ), 7.25 (1H, d, $J$ 12.4, H-8), 7.52 (1H, dd, $J 10.4$ and 9.6, H-5), 7.82 (1H, d, $J$ 12.4, H-7), 7.83 (1H, dd, $J$ 11.0 and 9.6, H-4), 8.05 (1H, d, $J$ 10.4, H-6), 8.56 (1H, s, H-11), and 8.71 (1H, d, $J$ 11.0, H-3) (OH was not observed); $v_{\max } / \mathrm{cm}^{-1} 3294(\mathrm{OH}), 1720,1690,1613(\mathrm{C}=\mathrm{O})$, and $1585(\mathrm{C}=\mathrm{C})$. Anal. Calcd for $\mathrm{C}_{19} \mathrm{H}_{13} \mathrm{NO}_{5}$ : C, 68.06; H, 3.91; N, 4.18. Found: C, 67.72; H, 3.86; N, 4.28.

\section{Biological assay}

HeLa S3 cells were obtained from AIST and used after cultivation. The cultivated HeLa S3 cells were cell counted and the culture fluid was prepared to the cell consistency of $2 \times 10^{4}$ cells/ml. The compounds added to the medium in DMSO solutions. To the aliquot of the culture fluid, which was incubated for $3 \mathrm{~h}$ at $37{ }^{\circ} \mathrm{C}$, the test sample was added and then the culture fluid was incubated for $72 \mathrm{~h}$. 
To the culture fluid, MTT (3-[4,5-dimethylthiazol]-2-yl-2,5-diphenyltetrazolium bromide) solution was added, and incubated for $4 \mathrm{~h}$. Then the sample was centrifuged at $3000 \mathrm{rpm}$ for $10 \mathrm{~min}$ at $4{ }^{\circ} \mathrm{C}$, and the solvent was evaporated. Then DMSO was added to the obtained mixture. The MTT-formazan was dissolved by plate-mixing and OD540 was measured. The rate of outlive determined to refer with un-dosed control. Dose-response curve was drawn up and $\mathrm{IC}_{50}$ was pursued. Every experiment in the cycotoxic assay was replicated twice in order to define the IC values.

\section{REFERENCES AND NOTES}

1. B. A. Hess, Jr. and L. J. Schaad, J. Org. Chem., 1971, 36, 3418.

2. T. Okazaki and K. K. Laali, Org. Biomol. Chem., 2003, 1, 3078.

3. A. Toyata and T. Nakajima, Tetrahedron, 1981, 37, 2575.

4. M. Saito, T. Morita, and K. Takase, Chem. Lett., 1974, 955.

5. $\quad$ M. Saito, T. Morita, and K. Takase, Chem. Lett., 1975, 441.

6. M. Yasunami, T. Amemiya, and K. Takase, Tetrahedron Lett., 1983, 24, 69.

7. C. Jutz, H. G. Peuker, and W. Kosbahn, Synthesis, 1976, 673.

8. T. Toda, N. Shimazaki, T. Mukai, and C. Kabuto, Tetrahedron Lett., 1980, 21, 4001.

9. Z. Yoshida, M. Shibata, E. Ogino, and T. Sugimoto, Tetrahedron Lett., 1984, 24, 3343.

10. S. Kuroda, S. Hirooka, H. Iwaki, M. Ikeda, T. Nakao, M. Ogisu, M. Yasunami, and K. Takase, Chem. Lett., 1986, 2039.

11. T. Takayasu and M. Nitta, J. Chem. Soc., Perkin Trans. 1, 1997, 3537.

12. For reviews see, N. Abe, 'Recent Research Developments in Organic and Bioorganic Chemistry' 2001, 4, 14, Transworld Research Network; T. Nishiwaki and N. Abe, Heterocycles, 1981, 15, 547; M. Kimura, Yuki Gosei Kagaku Kyokai Shi, 1981, 39, 690.

13. N. Hirata, M. Yasunami, and K. Takase, Tetrahedron Lett., 1975, 1849.

14. Y. Iino and M. Nitta, J. Chem. Soc., Perkin Trans. 1, 1994, 2579.

15. M. Nitta, Y. Iino, T. Sugiyama, and A. Toyota, Tetrahedron Lett., 1993, 34, 835.

16. M. Nitta, Y. Iino, T. Sugiyama, and A. Akaogi, Tetrahedron Lett., 1993, 34, 831.

17. K. Koizumi, C. Miyake, T. Ariyoshi, K. Umeda, N. Yamauchi, S. Tagashira, Y. Murakami, H. Fujii, and N. Abe, Heterocycles, 2007, 73, 325.

18. M. J. Frisch, G. W. Trucks, H. B. Schlegel, G. E. Scuseria, M. A. Robb, J. R. Cheeseman, J. A. Montgomery, Jr., T. Vreven, K. N. Kudin, J. C. Burant, J. M. Millam, S. S. Iyengar, J. Tomasi, V. Barone, B. Mennucci, M. Cossi, G. Scalmani, N. Rege, G. A. Petersson, H. Nakatsuji, M. Hada, M. Ehara, K. Toyota, R. Fukuda, J. Hasegawa, M. Ishida, T. Nakajima, Y. Honda, O. Kitao, H. Nakai, M. Klene, X. Li, J. E. Knox, H. P. Hratchian, J. B. Cross, C. Adamo, J. Jaramillo, R. Gomperts, R. 
E. Stratmann, O. Yazyev, A. J. Austin, R. Cammi, C. Pomelli, J. W. Ochterski, P. Y. Ayala, K. Morokuma, G. A. Voth, P. Salvador, J. J. Dnnenberg, V. G. Zakrezewski, S. Dapprich, A. D. Daniels, M. C. Strain, O. Farkas, D. K. Malick, A. D. Rabuck, K. Raghavachari, J. B. Foresman, J. V. Ortiz, Q. Cui, A. G. Baboul, S. Clifford, I. Komaromi, R. L. Martin, D. J. Fox, T. Keith, M. A. Al-Laham, C. Y. Peng, A. Nanayakkara, M. Chllacombe, P. M. W. Gill, B. Johnson, W. Chen, M. W. Wong, C, Gonzalez, and J. A. Pople, Gaussian 03, Gaussian, Inc., Pittsburgh, PA (2003).

19. M. Oda, M. Funamizu, and Y. Kitahara, Bull. Chem. Soc. Jpn., 1969, 42, 2386. 